\title{
Kebiasaan Merokok dan Terjadinya Smoker's Melanosis
}

\author{
Iin Revien, Aurelia S. R. Supit, Pritartha S. Anindita
}

\author{
Program Studi Pendidikan Dokter Gigi Fakultas Kedokteran Universitas Sam Ratulangi \\ Manado \\ Email: iinrevient@gmail.com
}

\begin{abstract}
Smoking can lead to a variety of systemic diseases as well as abnormal signs in the oral cavity inter alia smoker's melanosis. This study was aimed to obtain the description of smoking habit and the occurrence of smoker's melanosis in general viewed from three smoking indicators, as follows: frequency of smoking, duration of smoking, and types of cigarettes. This was a literature review study. There were 22 literatures consisting of 20 cross sectional studies dan 2 case control studies. The results showed that smoker's melanosis was more frequent in smokers than in non smokers. Based on the frequency of smoking, smoker's melanosis was most frequent in heavy smokers, followed by moderate smokers, and light smokers. Based on the duration of smoking, smoker's melanosis was most frequent in 10-year smokers, followed by 5-to-10-year smokers, and less-than-five-year smokers. Based on the types of cigarettes, smoker's melanosis was most frequent in smokers of clove/non filter cigarette, followed by smokers of white/filter cigarette, and smokers of both types of cigarette. In conclusion, smoker's melanosis was more frequent in smokers than in non smokers. The majority of cases were heavy smokers, had duration of smoking more than 10 years, and the type of cigarette consumed was clove/non filter cigarette.
\end{abstract}

Keywords: cigarettes, smoker's melanosis.

\begin{abstract}
Abstrak: Merokok dapat berdampak buruk bagi kesehatan. Berbagai penyakit sistemik di dalam tubuh dan tanda abnormal di rongga mulut dapat diakibatkan kebiasaan merokok, salah satunya smoker's melanosis. Penelitian ini bertujuan untuk mengetahui gambaran kebiasaan merokok dan terjadinya smoker's melanosis secara umum dilihat dari tiga indikator merokok, yaitu frekuensi merokok, durasi merokok, dan jenis rokok. Jenis penelitian ini ialah studi pustaka. Pustaka yang digunakan berjumlah 22 buah, terdiri dari 20 cross sectional study dan 2 case control study. Hasil penelitian ini memperlihatkan bahwa smoker's melanosis lebih banyak ditemukan pada individu yang merokok dibandingkan dengan yang tidak merokok. Berdasarkan frekuensi merokok, smoker's melanosis paling banyak ditemukan pada perokok berat, diikuti perokok sedang, dan perokok ringan. Berdasarkan durasi merokok, smoker's melanosis paling banyak ditemukan pada perokok dengan durasi $>10$ tahun, diikuti durasi 5-10 tahun, dan durasi $<5$ tahun. Berdasarkan jenis rokok, smoker's melanosis paling banyak ditemukan pada perokok dengan jenis rokok kretek/non filter/sigaret kretek, diikuti perokok dengan jenis rokok putih/filter, dan perokok dengan jenis keduanya. Simpulan penelitian ini ialah smoker's melanosis lebih banyak ditemukan pada perokok dibandingkan dengan yang bukan perokok, Mayoritas kasus ialah perokok berat, durasi merokok >10 tahun, dan mengonsumsi jenis rokok kretek/non filter/sigaret kretek.
\end{abstract}

Kata kunci: kebiasaan merokok, smoker's melanosis

\section{PENDAHULUAN}

Salah satu kebiasaan yang sulit untuk ditinggalkan masyarakat pada umumnya yaitu merokok. ${ }^{1}$ Pada tahun 2015, World Health Organization (WHO) melaporkan bahwa diperkirakan jumlah perokok di negara maju mencapai 300 juta perokok sedangkan di negara berkembang mendekati tiga kali lipat yaitu sebanyak 800 juta. Indonesia ditunjuk sebagai salah satu dari 
lima negara dengan jumlah perokok terbanyak di dunia, yakni 80,2 juta orang atau setara dengan $45 \%$ dari total penduduk Indonesia. $^{2}$ Menurut data Riset Kesehatan Dasar (RISKESDAS) tahun 2018, prevalensi merokok di Indonesia mencapai angka $28,8 \%$. $^{3}$

Rokok merupakan salah satu penyebab timbulnya berbagai penyakit di dalam tubuh. ${ }^{4}$ Selain menimbulkan efek sistemik, rokok juga dapat menyebabkan munculnya berbagai kondisi abnormal yang bersifat patologik maupun fisiologik di dalam rongga mulut, salah satunya smoker's melanosis. Nikitakis dan Brooks ${ }^{5}$ menyatakan bahwa smoker's melanosis erat kaitannya dengan aktivitas merokok. Beberapa indikator yang dapat dijadikan alat ukur untuk melihat aktivitas seseorang perokok, antara lain frekuensi merokok, durasi merokok, jenis rokok, dan cara menghisap rokok. Penelitian yang dilakukan oleh Tobangen dan Mintjelungan ${ }^{6}$ di Manado melaporkan bahwa dari 71 perokok, sebanyak $63,4 \%$ memperlihatkan smoker's melanosis, sedangkan sebanyak $36,6 \%$ tidak memperlihatkan smoker's melanosis.

Perubahan warna pigmentasi gingiva (smoker's melanosis) merupakan salah satu kondisi abnormal pada rongga mulut yang tidak berbahaya. ${ }^{7}$ Walaupun bersifat fisiologik, lesi ini dapat memengaruhi estetika seorang perokok. Estetika merupakan salah satu aspek penting didalam kehidupan yang berperan untuk menunjang penampilan. Selain itu, estetika juga dijadikan sebagai metode komunikasi untuk bersosialisasi dan meningkatkan rasa percaya diri seseorang, terutama bila individu tersenyum lebar hingga frenulum labial sampai sekitar attached gingiva terlihat (gummy smile). ${ }^{8}$ Penelitian yang dilakukan oleh Roshna dan Nandakumar ${ }^{9}$ di India menyebutkan bahwa seseorang dengan smoker's melanosis memiliki tingkat kepercayaan diri lebih rendah untuk senyum dan berbicara dengan orang sekitar dibandingkan seseorang dengan gingiva normal.

Smoker's melanosis merupakan keadaan abnormal namun bersifat reversibel yang tidak tergolong pre-malignant. Lesi ini timbul akibat kebiasaan merokok. ${ }^{9,10}$ Gambaran klinis lesi smoker's melanosis yaitu adanya bercak berwarna coklat difus yang menyebar dengan diameter kurang dari $1 \mathrm{~cm}$ dan letaknya paling sering nampak di gingiva anterior mandibula dan mukosa bukal. ${ }^{11,12}$ Tingginya prevalensi merokok dan angka kejadian smoker's melanosis membuat penulis merasa tertarik untuk meneliti kebiasaan merokok dan terjadinya smoker's melanosis melalui studi literatur.

\section{METODE PENELITIAN}

Penelitian ini merupakan studi pustaka (literature review). Populasi dalam penelitian ini yaitu seluruh jurnal dan artikel yang diperoleh dari database seperti PubMed, Wiley, Google scholar, research gate, dan medico research. Instrumen yang digunakan dalam penelitian ini yaitu The Joanna Briggs Institute (JBI) Critical Appraisal. Isi instrumen penelitian berupa daftar penilaian The JBI Critical Appraisal yang tersedia dalam bentuk checklist dimana setiap pertanyaan dinilai berdasarkan kriteria dan diberi nilai 'ya', 'tidak', 'tidak jelas', atau'tidak berlaku'. Setiap skor 'ya' diberi satu poin sedangkan nilai lainnya ialah nol. Hasil akhir penilaian studi dilihat dari jumlah skor yang didapatkan dan harus mencapai $50 \%$ agar studi terhitung dalam studi pustaka.

\section{HASIL PENELITIAN}

Pustaka yang digunakan dalam penelitian ini yaitu yang didapatkan dari berbagai database, seperti PubMed, Wiley, Google scholar, research gate, medico research menggunakan keyword smoker's melanosis. Pada penelitian ini, pustaka yang telah memenuhi kriteria inklusi dan eklusi serta kelayakan telah teruji berjumlah 22 buah, terdiri dari 20 cross-sectional study dan 2 case control study.

Tabel 1 memperlihatkan karakteristik pustaka yang berjumlah 22 buah, terdiri dari 13 pustaka Indonesia dan 9 pustaka luar negeri dengan jenis penelitian yakni 20 cross-sectional study dan 2 case control study. 
Tabel 1. Karakteristik pustaka

\begin{tabular}{|c|c|c|c|c|c|c|c|c|c|}
\hline No & Penulis & $\begin{array}{l}\text { Lokasi } \\
\text { Penelitian }\end{array}$ & $\begin{array}{c}\text { Jumlah } \\
\text { sampel }\end{array}$ & $\begin{array}{l}\text { Jumlah } \\
\text { populasi }\end{array}$ & $\begin{array}{c}\text { Karakteristik } \\
\text { populasi }\end{array}$ & $\begin{array}{c}\text { Jenis } \\
\text { penelitian }\end{array}$ & Tahun & $\begin{array}{c}\text { Usia } \\
\text { sampel }\end{array}$ & $\begin{array}{l}\text { Jenis } \\
\text { kelamin }\end{array}$ \\
\hline 1. & $\begin{array}{l}\text { Tobangen, } \\
\text { Mintjelungan }\end{array}$ & $\begin{array}{l}\text { Manado, } \\
\text { Indonesia }\end{array}$ & 71 & 242 & Mahasiswa FK & $\begin{array}{c}\text { cross-sectional } \\
\text { observational } \\
\text { study }\end{array}$ & 2011 & $\begin{array}{l}18-22 \\
\text { tahun }\end{array}$ & $\begin{array}{l}\text { L: } 242 \\
\text { P: } 0\end{array}$ \\
\hline 2. & Melda $^{13}$ & $\begin{array}{l}\text { Sidrap, } \\
\text { Indonesia }\end{array}$ & 110 & 1220 & Petani & $\begin{array}{c}\text { cross-sectional } \\
\text { study }\end{array}$ & 2014 & $\begin{array}{l}15-75 \\
\text { tahun }\end{array}$ & $\begin{array}{l}\mathrm{L}: 1220 \\
\mathrm{P}: 0\end{array}$ \\
\hline 3. & Faruchy et al ${ }^{14}$ & $\begin{array}{l}\text { Bandung, } \\
\text { Indonesia }\end{array}$ & 49 & 49 & Pasien di RSGM & $\begin{array}{c}\text { cross-sectional } \\
\text { study }\end{array}$ & 2018 & $\begin{array}{l}15-65 \\
\text { tahun }\end{array}$ & $\begin{array}{l}\mathrm{L}: 47 \\
\mathrm{P}: 2\end{array}$ \\
\hline 4. & Multani $^{15}$ & India & 109 & 218 & Pasien di RSGM & $\begin{array}{c}\text { cross-sectional } \\
\text { observational } \\
\text { study }\end{array}$ & 2013 & $\begin{array}{l}35-44 \\
\text { tahun }\end{array}$ & $\begin{array}{l}\text { L: } 218 \\
P: 0\end{array}$ \\
\hline 5. & Nadeem et al ${ }^{16}$ & Pakistan & 103 & 378 & $\begin{array}{c}\text { Masyarakat } \\
\text { Pakistan }\end{array}$ & $\begin{array}{c}\text { cross-sectional } \\
\text { study }\end{array}$ & 2011 & $\begin{array}{l}18-35 \\
\text { tahun }\end{array}$ & $\begin{array}{l}\text { L: } 378 \\
\text { P: } 0\end{array}$ \\
\hline 6. & $\mathrm{Tia}^{17}$ & Aceh, Indonesia & 149 & 260 & Mahasiswa FT & $\begin{array}{c}\text { cross-sectional } \\
\text { study }\end{array}$ & 2015 & $\begin{array}{l}18-24 \\
\text { tahun }\end{array}$ & $\begin{array}{l}\mathrm{L}: 260 \\
\mathrm{P}: 0\end{array}$ \\
\hline 7. & $\begin{array}{l}\text { Simbolon } \\
\text { et al }\end{array}$ & $\begin{array}{l}\text { Medan, } \\
\text { Indonesia }\end{array}$ & 56 & 67 & Siswa SMA & $\begin{array}{c}\text { cross-sectional } \\
\text { study }\end{array}$ & 2016 & $\begin{array}{l}15-17 \\
\text { tahun }\end{array}$ & $\begin{array}{l}\mathrm{L}: 67 \\
\mathrm{P}: 0\end{array}$ \\
\hline 8. & Sitepu $^{19}$ & $\begin{array}{l}\text { Sumatera Utara, } \\
\text { Indonesia }\end{array}$ & 82 & 164 & $\begin{array}{c}\text { Mahasiswa } \\
\text { FMIPA }\end{array}$ & $\begin{array}{c}\text { cross-sectional } \\
\text { study }\end{array}$ & 2010 & $\begin{array}{l}18-25 \\
\text { tahun }\end{array}$ & $\begin{array}{l}\text { L: } 164 \\
P: 0\end{array}$ \\
\hline 9. & $\begin{array}{l}\text { Nurisriani, } \\
\text { Firmansyah }^{20}\end{array}$ & $\begin{array}{l}\text { Polewali } \\
\text { Mandar, } \\
\text { Indonesia }\end{array}$ & 64 & 173 & $\begin{array}{l}\text { Masyarakat } \\
\text { Polewali }\end{array}$ & $\begin{array}{c}\text { cross-sectional } \\
\text { study }\end{array}$ & 2017 & $\begin{array}{l}15-36 \\
\text { tahun }\end{array}$ & $\begin{array}{l}\text { L: } 172 \\
\text { P: } 1\end{array}$ \\
\hline 10. & Yosadi et $\mathrm{al}^{21}$ & $\begin{array}{l}\text { Bolaang } \\
\text { Mongondow } \\
\text { Timur, } \\
\text { Indonesia }\end{array}$ & 45 & 70 & Petani & $\begin{array}{c}\text { cross-sectional } \\
\text { study }\end{array}$ & 2015 & $\begin{array}{l}25-60 \\
\text { tahun }\end{array}$ & $\begin{array}{l}\text { L: } 70 \\
P: 0\end{array}$ \\
\hline 11. & Triza, Afriza ${ }^{22}$ & $\begin{array}{l}\text { Padang, } \\
\text { Indonesia }\end{array}$ & 40 & 80 & Pasien di RSGM & $\begin{array}{c}\text { case control } \\
\text { study }\end{array}$ & 2014 & $\begin{array}{l}18-25 \\
\text { tahun }\end{array}$ & $\begin{array}{l}\text { L: } 80 \\
P: 0\end{array}$ \\
\hline 12. & Pratiwi et al ${ }^{23}$ & $\begin{array}{l}\text { Padang, } \\
\text { Indonesia }\end{array}$ & 30 & 30 & Buruh bangunan & $\begin{array}{c}\text { cross-sectional } \\
\text { observational } \\
\text { study }\end{array}$ & 2017 & $\begin{array}{l}>50 \\
\text { tahun }\end{array}$ & $\begin{array}{l}\mathrm{L}: 30 \\
\mathrm{P}: 0\end{array}$ \\
\hline 13. & Rangkuti $^{24}$ & $\begin{array}{l}\text { Medan, } \\
\text { Indonesia }\end{array}$ & 132 & 132 & Pegawai kantor & $\begin{array}{c}\text { cross-sectional } \\
\text { study }\end{array}$ & 2019 & $\begin{array}{l}>55 \\
\text { tahun }\end{array}$ & $\begin{array}{l}\text { L: } 132 \\
P: 0\end{array}$ \\
\hline 14. & Akbar et $\mathrm{al}^{25}$ & $\begin{array}{l}\text { Bandung, } \\
\text { Indonesia }\end{array}$ & 90 & 132 & Pasien di RSGM & $\begin{array}{c}\text { cross-sectional } \\
\text { study }\end{array}$ & 2017 & $\begin{array}{l}18-23 \\
\text { tahun }\end{array}$ & $\begin{array}{l}\text { L: } 132 \\
P: 0\end{array}$ \\
\hline 15. & Hanioka et $\mathrm{al}^{26}$ & Jepang & 153 & 282 & $\begin{array}{c}\text { Pegawai } \\
\text { perusahaan }\end{array}$ & $\begin{array}{c}\text { cross-sectional } \\
\text { observational } \\
\text { study }\end{array}$ & 2010 & $\begin{array}{l}20-59 \\
\text { tahun }\end{array}$ & $\begin{array}{l}\mathrm{L}: 282 \\
\mathrm{P}: 0\end{array}$ \\
\hline 16. & Haresaku et $\mathrm{al}^{27}$ & Jepang & 280 & 426 & Pasien di RSGM & $\begin{array}{c}\text { case control } \\
\text { study }\end{array}$ & 2010 & $\begin{array}{l}>32 \\
\text { tahun }\end{array}$ & $\begin{array}{l}\mathrm{L}: 426 \\
\mathrm{P}: 0\end{array}$ \\
\hline 17. & Goyal, Devaraj $^{28}$ & India & 75 & 150 & Pasien di RSGM & $\begin{array}{c}\text { cross-sectional } \\
\text { comparative } \\
\text { study }\end{array}$ & 2017 & $\begin{array}{l}20-60 \\
\text { tahun }\end{array}$ & $\begin{array}{l}\text { L: } 150 \\
P: 0\end{array}$ \\
\hline 18. & Unsal et $\mathrm{al}^{29}$ & Turki & 268 & 496 & Masyarakat Turki & $\begin{array}{c}\text { cross-sectional } \\
\text { study }\end{array}$ & 2010 & $\begin{array}{l}>33 \\
\text { tahun }\end{array}$ & $\begin{array}{l}\text { L: } 228 \\
\text { P: } 268\end{array}$ \\
\hline 19. & Fatimah et $\mathrm{al}^{30}$ & $\begin{array}{l}\text { Bandung, } \\
\text { Indonesia }\end{array}$ & 50 & 50 & Pasien di RSGM & $\begin{array}{c}\text { cross-sectional } \\
\text { observational } \\
\text { study }\end{array}$ & 2017 & $\begin{array}{l}18-24 \\
\text { tahun }\end{array}$ & $\begin{array}{l}\mathrm{L}: 0 \\
\mathrm{P}: 50\end{array}$ \\
\hline 20. & Abdulnasser,Nasser ${ }^{31}$ & Brazil & 118 & 440 & $\begin{array}{c}\text { Masyarakat } \\
\text { Yemeni }\end{array}$ & $\begin{array}{c}\text { cross-sectional } \\
\text { study }\end{array}$ & 2019 & $\begin{array}{l}>25 \\
\text { tahun }\end{array}$ & $\begin{array}{l}\text { L: } 225 \\
\text { P: } 215\end{array}$ \\
\hline 21. & Nwhator et al ${ }^{32}$ & Nigeria & 60 & 253 & $\begin{array}{c}\text { Masyarakat } \\
\text { Nigeria }\end{array}$ & $\begin{array}{c}\text { cross-sectional } \\
\text { study }\end{array}$ & 2017 & $\begin{array}{l}>20 \\
\text { tahun }\end{array}$ & $\begin{array}{l}\mathrm{L}: 253 \\
\mathrm{P}: 0\end{array}$ \\
\hline 22. & Marakoglu et $\mathrm{al}^{33}$ & Turki & 608 & 908 & Tentara & $\begin{array}{c}\text { cross-sectional } \\
\text { study }\end{array}$ & 2010 & $\begin{array}{l}20-31 \\
\text { tahun }\end{array}$ & $\begin{array}{l}\text { L: } 908 \\
P: 0\end{array}$ \\
\hline
\end{tabular}

Tabel 2 memperlihatkan bahwa responden dengan kebiasaan merokok yang mengalami smoker's melanosis ditemukan di 22 pustaka dan yang tidak mengalami smoker's melanosis ditemukan di 21 pus- taka. Responden tanpa kebiasaan merokok (tidak merokok), yang mengalami smoker's melanosis dan yang tidak mengalami smoker's melanosis ditemukan di 21 pustaka. 
Tabel 2. Gambaran kebiasaan merokok dan smoker's melanosis

\begin{tabular}{|c|c|c|c|c|c|c|c|c|c|c|}
\hline \multirow{3}{*}{ No } & \multirow{3}{*}{ Penulis } & \multirow{3}{*}{ Lokasi Penelitian } & \multicolumn{4}{|c|}{ Merokok } & \multicolumn{4}{|c|}{ Tidak merokok } \\
\hline & & & \multicolumn{2}{|c|}{$\begin{array}{l}\text { Smoker's } \\
\text { melanosis }\end{array}$} & \multicolumn{2}{|c|}{$\begin{array}{c}\text { Tidak smoker's } \\
\text { melanosis }\end{array}$} & \multicolumn{2}{|c|}{$\begin{array}{l}\text { Smoker's } \\
\text { melanosis }\end{array}$} & \multicolumn{2}{|c|}{$\begin{array}{c}\text { Tidak smoker's } \\
\text { melanosis }\end{array}$} \\
\hline & & & $\mathrm{n}$ & $\%$ & $\mathrm{n}$ & $\%$ & $\mathrm{n}$ & $\%$ & $\mathrm{n}$ & $\%$ \\
\hline 1. & $\begin{array}{l}\text { Tobangen, } \\
\text { Mintjelungan }^{6}\end{array}$ & Manado, Indonesia & 45 & 63,4 & 26 & 36,6 & - & - & - & - \\
\hline 2. & Melda $^{13}$ & Sidrap, Indonesia & 94 & 85,5 & 16 & 14,5 & - & - & - & - \\
\hline 3. & Faruchy et al ${ }^{14}$ & $\begin{array}{l}\text { Bandung, } \\
\text { Indonesia }\end{array}$ & 44 & 89,8 & 5 & 10,2 & - & - & - & - \\
\hline 4. & Multani $^{15}$ & India & 108 & 99,1 & 1 & 0,9 & 80 & 73,4 & 29 & 26,6 \\
\hline & Nadeem et al ${ }^{16}$ & Pakistan & 40 & 38,8 & 63 & 61,2 & 26 & 9,5 & 249 & 90,5 \\
\hline & $\mathrm{Tia}^{17}$ & Aceh, Indonesia & 138 & 92,6 & 11 & 7,4 & - & - & - & - \\
\hline & $\begin{array}{l}\text { Simbolon } \\
\text { et al }\end{array}$ & Medan, Indonesia & 34 & 60,7 & 22 & 39,3 & 1 & 9,1 & 10 & 90,0 \\
\hline & Sitepu ${ }^{19}$ & $\begin{array}{l}\text { Sumatera Utara, } \\
\text { Indonesia }\end{array}$ & 53 & 64,6 & 29 & 35,7 & 9 & 10,9 & 73 & 89,0 \\
\hline & $\begin{array}{l}\text { Nurisriani, } \\
\text { Firmansyah }^{20}\end{array}$ & $\begin{array}{l}\text { Polewali Mandar, } \\
\text { Indonesia }\end{array}$ & 47 & 73,4 & 17 & 26,6 & - & - & - & - \\
\hline & Yosadi et $\mathrm{al}^{21}$ & $\begin{array}{l}\text { Bolaang Mongondow } \\
\text { Timur, Indonesia }\end{array}$ & 41 & 91,1 & 4 & 8,9 & 3 & 12,0 & 22 & 88,0 \\
\hline 11. & Triza, Afriza ${ }^{22}$ & Padang, Indonesia & 26 & 65,0 & 14 & 35,0 & 5 & 12,5 & 35 & 87,5 \\
\hline 12. & Pratiwi et $\mathrm{al}^{23}$ & Padang, Indonesia & 30 & 100 & 0 & 0 & - & - & - & - \\
\hline 13. & Rangkuti $^{24}$ & Medan, Indonesia & 131 & 99,3 & 1 & 0.7 & - & - & - & - \\
\hline 14. & Akbar et $\mathrm{al}^{25}$ & $\begin{array}{l}\text { Bandung, } \\
\text { Indonesia }\end{array}$ & 58 & 64,4 & 32 & 35,6 & - & - & - & - \\
\hline 15. & Hanioka et $\mathrm{al}^{26}$ & Jepang & 126 & 82,4 & 27 & 17,6 & 37 & 28,7 & 92 & 71,3 \\
\hline 16. & Haresaku et al ${ }^{27}$ & Jepang & 213 & 76,1 & 67 & 23,9 & 48 & 32,9 & 98 & 67,1 \\
\hline 17. & Goyal, Devaraj $^{28}$ & India & 68 & 90,7 & 7 & 9,3 & 16 & 21,3 & 59 & 78,7 \\
\hline 18. & Unsal et $\mathrm{al}^{29}$ & Turki & 94 & 35,1 & 174 & 64,9 & 27 & 11,8 & 201 & 88,2 \\
\hline 19. & Fatimah et $\mathrm{al}^{30}$ & $\begin{array}{l}\text { Bandung, } \\
\text { Indonesia }\end{array}$ & 46 & 92,0 & 4 & 8,0 & - & - & - & - \\
\hline 20. & Abdulnasser,Nasser ${ }^{31}$ & Brazil & 95 & 80,5 & 23 & 19,5 & 181 & 55,2 & 141 & 44,8 \\
\hline 21. & Nwhator et $\mathrm{al}^{32}$ & Nigeria & 18 & 30,0 & 42 & 70,0 & 5 & 2,6 & 188 & 97,4 \\
\hline 22. & Marakoglu et $\mathrm{al}^{33}$ & Turki & 169 & 27,8 & 439 & 72,2 & 26 & 8,6 & 274 & 91,4 \\
\hline
\end{tabular}

Tabel 3 menunjukkan bahwa pada perokok ringan, yang mengalami smoker's melanosis ditemukan di 15 pustaka dan yang tidak mengalami smoker's melanosis ditemukan di 22 pustaka. Pada perokok sedang, yang mengalami smoker's melanosis ditemukan di 21 pustaka dan yang tidak mengalami smoker's melanosis ditemukan di 19 pustaka. Pada perokok berat, yang mengalami smoker's melanosis ditemukan di 22 pustaka dan yang tidak mengalami smoker's melanosis ditemukan di 10 pustaka.

Tabel 4 menunjukkan bahwa pada perokok yang merokok $<5$ tahun, yang mengalami smoker's melanosis dan yang tidak mengalami smoker's melanosis ditemukan di 18 pustaka Pada perokok yang merokok 5-10 tahun, yang mengalami smoker's melanosis ditemukan di 21 pustaka dan yang tidak mengalami smoker's melanosis ditemukan di 18 pustaka. Pada perokok yang merokok $>10$ tahun, yang mengalami smoker's melanosis ditemukan di semua pustaka yakni 22 pustaka dan yang tidak mengalami smoker's melanosis ditemukan di 17 pustaka.

Tabel 5 menunjukkan bahwa pada perokok dengan jenis kretek/non filter/ sigaret kretek, yang mengalami smoker's melanosis ditemukan di 22 pustaka dan yang tidak mengalami smoker's melanosis ditemukan di 16 pustaka. Pada perokok dengan jenis rokok putih/filter, yang mengalami smoker's melanosis ditemukan di 17 pustaka dan yang tidak mengalami smoker's melanosis ditemukan di 14 pustaka Pada perokok dengan jenis keduanya yaitu kretek dan putih/non filter dan filter, yang mengalami smoker's melanosis ditemukan di 11 pustaka dan yang tidak mengalami smoker's melanosis di 8 pustaka. 
Tabel 3. Gambaran kebiasaan merokok dan smoker's melanosis berdasarkan frekuensi merokok

\begin{tabular}{|c|c|c|c|c|c|c|c|c|c|c|c|c|c|c|}
\hline \multirow{3}{*}{ No } & \multirow{3}{*}{ Penulis } & \multirow{3}{*}{ Lokasi Penelitian } & \multicolumn{4}{|c|}{ Perokok ringan } & \multicolumn{4}{|c|}{ Perokok sedang } & \multicolumn{4}{|c|}{ Perokok berat } \\
\hline & & & \multicolumn{2}{|c|}{$\begin{array}{l}\text { Smoker's } \\
\text { melanosis }\end{array}$} & \multicolumn{2}{|c|}{$\begin{array}{c}\text { Tidak } \\
\text { smoker's } \\
\text { melanosis }\end{array}$} & \multicolumn{2}{|c|}{$\begin{array}{l}\text { Smoker's } \\
\text { melanosis }\end{array}$} & \multicolumn{2}{|c|}{$\begin{array}{c}\text { Tidak } \\
\text { smoker's } \\
\text { melanosis }\end{array}$} & \multicolumn{2}{|c|}{$\begin{array}{l}\text { Smoker's } \\
\text { melanosis }\end{array}$} & \multicolumn{2}{|c|}{$\begin{array}{c}\text { Tidak } \\
\text { smoker's } \\
\text { melanosis }\end{array}$} \\
\hline & & & $\mathrm{n}$ & $\%$ & $\mathrm{n}$ & $\%$ & $\mathrm{n}$ & $\%$ & $\mathrm{n}$ & $\%$ & $\mathrm{n}$ & $\%$ & $\mathrm{n}$ & $\%$ \\
\hline 1. & $\begin{array}{l}\text { Tobangen, } \\
\text { Mintjelungan }\end{array}$ & $\begin{array}{l}\text { Manado, } \\
\text { Indonesia }\end{array}$ & 6 & 8,5 & 13 & 18,3 & 19 & 26,7 & 8 & 11,3 & 20 & 28,2 & 5 & 7,0 \\
\hline 2. & Melda $^{13}$ & Sidrap, Indonesia & 0 & 0 & 10 & 9,1 & 19 & 17,3 & 6 & 5,4 & 75 & 68,2 & 0 & 0 \\
\hline 3. &  & $\begin{array}{l}\text { Bandung, } \\
\text { Indonesia }\end{array}$ & 20 & 40,8 & 2 & 4,1 & 17 & 34,7 & 3 & 6,1 & 7 & 14,3 & 0 & 0 \\
\hline 4. & Multani $^{15}$ & India & 10 & 9,2 & 1 & 0,9 & 36 & 33,0 & 3 & 2,7 & 59 & 54,2 & 0 & 0 \\
\hline 5. & Nadeem et al ${ }^{16}$ & Pakistan & 3 & 2,9 & 30 & 29,1 & 4 & 3,9 & 31 & 30,1 & 33 & 32,0 & 2 & 2,0 \\
\hline 6. & $\mathrm{Tia}^{17}$ & ndor & 3 & 2,0 & 15 & 10,1 & 30 & 20,1 & 4 & 2,7 & 93 & 62,4 & 4 & 2,7 \\
\hline 7. & $\begin{array}{l}\text { Simbolon } \\
\text { et a } 1^{18}\end{array}$ & $\mathrm{Me}$ & 22 & 39,3 & 19 & 33,9 & - & - & - & - & 12 & 21,4 & 3 & 5,4 \\
\hline 8. & Sitepu $^{19}$ & $\begin{array}{l}\text { Sumatera Utara, } \\
\text { Indonesia }\end{array}$ & 0 & 0 & 15 & 18,3 & 25 & 30,5 & 13 & 15,9 & 28 & 34,1 & 1 & 1,2 \\
\hline 9. & $\begin{array}{l}\text { Nurisriani, } \\
\text { Firmansyah }^{20}\end{array}$ & $\begin{array}{l}\text { Polewali Mandar, } \\
\text { Indonesia }\end{array}$ & 1 & 1,6 & 5 & 7,8 & 7 & 10,9 & 1 & 1,6 & 45 & 70,3 & 5 & 7,8 \\
\hline & Yosadi et al $^{21}$ & Bolaang & & & & & & & & & & & & \\
\hline & & $\begin{array}{l}\text { Mongondow } \\
\text { Timur, Indonesia }\end{array}$ & 0 & 0 & 6 & 13,3 & 7 & 15,6 & 7 & 15,6 & 25 & 55,5 & 0 & 0 \\
\hline 11. & Triza, Afriza ${ }^{22}$ & Padang, Indonesia & 0 & 0 & 7 & 17,5 & 17 & 42,5 & 2 & 5,0 & 14 & 35,0 & 0 & 0 \\
\hline 12. & Pratiwi et $\mathrm{al}^{23}$ & Indonesia & 0 & 0 & 2 & 6,7 & 4 & 13,3 & 2 & 6,7 & 22 & 73,3 & 0 & 0 \\
\hline 13. & Rangkuti ${ }^{24}$ & Medan, Indonesia & 48 & 36,4 & 1 & 0,7 & 41 & 31,1 & 0 & 0 & 42 & 31,8 & 0 & 0 \\
\hline 14. & Akbar et $\mathrm{al}^{25}$ & $\begin{array}{l}\text { Band } \\
\text { Indor }\end{array}$ & 8 & 8,9 & 22 & 24,4 & 24 & 26,7 & 6 & 6,7 & 26 & 28,9 & 4 & 4,4 \\
\hline 15. & Hanic & Jepa & 0 & U & 23 & 15,0 & 55 & 36,0 & 31 & 20,3 & 44 & 28,7 & 0 & 0 \\
\hline 16. & Hares & Jepang & 12 & 4,3 & 55 & 19,6 & 60 & 21,4 & 3 & 1,1 & 145 & 51,8 & 5 & 1,8 \\
\hline 17. & Goyal, Devaraj $^{28}$ & India & 5 & 6,7 & 23 & 30,6 & 20 & 26,7 & 5 & 6,7 & 16 & 21,3 & 6 & 8,0 \\
\hline 18. & Unsal & & 0 & 2,2 & 77 & 28,7 & 90 & 33,6 & 12 & 4,5 & 83 & 31,0 & 0 & 0 \\
\hline 19. & Fatimah et $\mathrm{al}^{30}$ & $\begin{array}{l}\text { Bandung, } \\
\text { Indonesia }\end{array}$ & 7 & 14,0 & 4 & 8,0 & 25 & 50,0 & 0 & 0 & 14 & 28,0 & 0 & 0 \\
\hline 20. & ,Nasser ${ }^{3}$ & ${ }^{1}$ Brazil & 0 & 0 & 12 & 10,2 & 28 & 23,7 & 3 & 2,5 & 75 & 63,6 & 0 & 0 \\
\hline 21. & Nwha & Nigeria & 2 & 3,3 & 2 & 3,3 & 11 & 18,3 & 5 & 8,3 & 40 & 66,8 & 0 & 0 \\
\hline 22. & Marakoglu et al ${ }^{33}$ & Turki & 8 & 1,3 & 66 & 10,8 & 25 & 4,2 & 64 & 10,5 & 143 & 23,5 & 302 & 49,7 \\
\hline
\end{tabular}

Tabel 4. Gambaran kebiasaan merokok dan smoker's melanosis berdasarkan durasi merokok

\begin{tabular}{|c|c|c|c|c|c|c|c|c|c|c|c|c|c|c|}
\hline \multirow{3}{*}{ No } & \multirow{3}{*}{ Penulis } & \multirow{3}{*}{$\begin{array}{l}\text { Lokasi } \\
\text { Penelitian }\end{array}$} & \multicolumn{4}{|c|}{$<5$ tahun } & \multicolumn{4}{|c|}{ 5-10 tahun } & \multicolumn{4}{|c|}{$>10$ tahun } \\
\hline & & & \multicolumn{2}{|c|}{$\begin{array}{l}\text { Smoker's } \\
\text { melanosis }\end{array}$} & \multicolumn{2}{|c|}{$\begin{array}{c}\text { Tidak } \\
\text { smoker's } \\
\text { melanosis }\end{array}$} & \multicolumn{2}{|c|}{$\begin{array}{l}\text { Smoker's } \\
\text { melanosis }\end{array}$} & \multicolumn{2}{|c|}{$\begin{array}{c}\text { Tidak } \\
\text { smoker's } \\
\text { melanosis }\end{array}$} & \multicolumn{2}{|c|}{$\begin{array}{l}\text { Smoker's } \\
\text { melanosis }\end{array}$} & \multicolumn{2}{|c|}{$\begin{array}{c}\text { Tidak } \\
\text { smoker's } \\
\text { melanosis }\end{array}$} \\
\hline & & & $\mathrm{n}$ & $\%$ & $\mathrm{n}$ & $\%$ & $\mathrm{n}$ & $\%$ & $\mathrm{n}$ & $\%$ & $\mathrm{~N}$ & $\%$ & $\mathrm{n}$ & $\%$ \\
\hline 1. & $\begin{array}{l}\text { Tobangen, } \\
\text { Mintjelungan }\end{array}$ & $\begin{array}{l}\text { Manado, } \\
\text { Indonesia }\end{array}$ & 9 & 12,7 & 7 & 9,8 & 10 & 14,1 & 10 & 14,1 & 26 & 36,6 & 9 & 12,7 \\
\hline 2. & Melda $^{13}$ & $\begin{array}{l}\text { Sidrap, } \\
\text { Indonesia }\end{array}$ & 0 & 0 & 10 & 9,1 & 6 & 5,5 & 5 & 4,5 & 88 & 80,0 & 1 & 0,9 \\
\hline 3. & Faruchy et al ${ }^{14}$ & $\begin{array}{l}\text { Bandung, } \\
\text { Indonesia }\end{array}$ & 8 & 16,3 & 0 & 0 & 12 & 24,5 & 2 & 4,1 & 24 & 49,0 & 3 & 6,1 \\
\hline 4. & Multani ${ }^{15}$ & India & 10 & 9,2 & 1 & 0,9 & 36 & 33,0 & 3 & 2,7 & 49 & 44,2 & 10 & 10,0 \\
\hline 5. & Nadeem et al ${ }^{16}$ & Pakistan & 3 & 2,9 & 11 & 10,7 & 5 & 4,9 & 9 & 8,7 & 32 & 31,1 & 43 & 41,7 \\
\hline 6. & $\operatorname{Tia}^{17}$ & $\begin{array}{l}\text { Aceh, } \\
\text { Indonesia }\end{array}$ & 0 & 0 & 5 & 3,4 & 38 & 25,5 & 10 & 6,7 & 95 & 63,8 & 1 & 0,6 \\
\hline 7. & $\begin{array}{l}\text { Simbolon } \\
\text { et al }^{18}\end{array}$ & $\begin{array}{l}\text { Medan, } \\
\text { Indonesia }\end{array}$ & 9 & 16,1 & 14 & 25,0 & 10 & 17,9 & 5 & 8,9 & 15 & 26,8 & 3 & 5,3 \\
\hline 8. & Sitepu $^{19}$ & $\begin{array}{l}\text { Sumatera } \\
\text { Utara, } \\
\text { Indonesia }\end{array}$ & 2 & 2,4 & 21 & 25,7 & 12 & 14,6 & 7 & 8,5 & 39 & 47,6 & 1 & 1,2 \\
\hline 9. & $\begin{array}{l}\text { Nurisriani, } \\
\text { Firmansyah }^{20}\end{array}$ & $\begin{array}{l}\text { Polewali } \\
\text { Mandar, } \\
\text { Indonesia }\end{array}$ & - & - & - & - & 2 & 3,1 & 12 & 18,8 & 45 & 70,3 & 5 & 7,8 \\
\hline
\end{tabular}




\begin{tabular}{|c|c|c|c|c|c|c|c|c|c|c|c|c|c|}
\hline 10. Yosadi et $\mathrm{al}^{21}$ & $\begin{array}{l}\text { Bolaang } \\
\text { Mongondow } \\
\text { Timur, } \\
\text { Indonesia }\end{array}$ & 2 & 4,4 & 8 & 17,8 & 6 & 13,4 & 2 & 4,4 & 22 & 48,9 & 5 & 11,1 \\
\hline 11. Triza, Afriza ${ }^{22}$ & $\begin{array}{l}\text { Padang, } \\
\text { Indonesia }\end{array}$ & 1 & 2,5 & 10 & 25,0 & 6 & 15,0 & 3 & 7,5 & 15 & 37,5 & 5 & 12,5 \\
\hline 12. Pratiwi et $\mathrm{al}^{23}$ & $\begin{array}{l}\text { Padang, } \\
\text { Indonesia }\end{array}$ & - & - & - & - & 8 & 26,7 & 0 & 0 & 22 & 73,3 & 0 & 0 \\
\hline 13. Rangkuti ${ }^{24}$ & $\begin{array}{l}\text { Medan, } \\
\text { Indonesia }\end{array}$ & 14 & 10,6 & 1 & 0,8 & 54 & 40,9 & 0 & 0 & 63 & 47,7 & 0 & 0 \\
\hline 14. Akbar et $\mathrm{al}^{25}$ & $\begin{array}{l}\text { Bandung, } \\
\text { Indonesia }\end{array}$ & 8 & 8,9 & 22 & 24,4 & 24 & 26,7 & 6 & 6,7 & 26 & 28,9 & 4 & 4,4 \\
\hline 15. Hanioka et $\mathrm{al}^{26}$ & Jepang & 5 & 3,3 & 9 & 5,9 & 40 & 26,1 & 22 & 14,4 & 70 & 45,7 & 7 & 4,6 \\
\hline 16. Haresaku et $\mathrm{al}^{27}$ & Jepang & 9 & 3,2 & 34 & 12,1 & 26 & 9,3 & 19 & 6,8 & 147 & 52,5 & 45 & 16,1 \\
\hline 17. Goyal, Devaraj ${ }^{28}$ & India & 5 & 6,7 & 15 & 20,0 & 20 & 26,7 & 6 & 8,0 & 29 & 38,6 & 0 & 0 \\
\hline 18. Unsal et $\mathrm{a}^{29}$ & Turki & 4 & 1,5 & 8 & 3,0 & 55 & 20,5 & 20 & 7,5 & 171 & 63,8 & 10 & 3,7 \\
\hline 19. Fatimah et $\mathrm{al}^{30}$ & $\begin{array}{l}\text { Bandung, } \\
\text { Indonesia }\end{array}$ & 7 & 14,0 & 4 & 8,0 & 22 & 44,0 & 0 & 0 & 17 & 34,0 & 0 & 0 \\
\hline 20. Abdulnasser,Nasser ${ }^{31}$ & Brazil & 24 & 20,3 & 22 & 18,6 & - & - & - & - & 71 & 60,3 & 1 & 0,8 \\
\hline 21. Nwhator et $\mathrm{al}^{32}$ & Nigeria & 2 & 3,3 & 0 & 0 & 6 & 10,0 & 10 & 16,7 & 42 & 70,0 & 0 & 0 \\
\hline 22. Marakoglu et al ${ }^{33}$ & Turki & 16 & 2,6 & 20 & 3,3 & 180 & 29,7 & 84 & 13,8 & 281 & 46,2 & 27 & 4,4 \\
\hline
\end{tabular}

Tabel 5. Gambaran kebiasaan merokok dan smoker's melanosis berdasarkan jenis rokok

\begin{tabular}{|c|c|c|c|c|c|c|c|c|c|c|c|c|c|c|}
\hline \multirow{3}{*}{ No } & \multirow{3}{*}{ Penulis } & \multirow{3}{*}{$\begin{array}{l}\text { Lokasi } \\
\text { Penelitian }\end{array}$} & \multicolumn{4}{|c|}{$\begin{array}{c}\text { Kretek/non filter/sigaret } \\
\text { kretek }\end{array}$} & \multicolumn{4}{|c|}{ Putih/ filter } & \multicolumn{4}{|c|}{$\begin{array}{c}\text { Campuran } \\
\text { (kretek dan putih / } \\
\text { non filter dan filter) }\end{array}$} \\
\hline & & & \multicolumn{2}{|c|}{$\begin{array}{l}\text { Smoker's } \\
\text { melanosis }\end{array}$} & \multicolumn{2}{|c|}{$\begin{array}{c}\text { Tidak smoker's } \\
\text { melanosis }\end{array}$} & \multicolumn{2}{|c|}{$\begin{array}{l}\text { Smoker's } \\
\text { melanosis }\end{array}$} & \multicolumn{2}{|c|}{$\begin{array}{c}\text { Tidak smoker's } \\
\text { melanosis }\end{array}$} & \multicolumn{2}{|c|}{$\begin{array}{l}\text { Smoker's } \\
\text { melanosis }\end{array}$} & \multicolumn{2}{|c|}{$\begin{array}{c}\text { Tidak smoker's } \\
\text { melanosis }\end{array}$} \\
\hline & & & $\mathrm{n}$ & $\%$ & $\mathrm{~N}$ & $\%$ & $\mathrm{n}$ & $\%$ & $\mathrm{n}$ & $\%$ & $\mathrm{~N}$ & $\%$ & $\mathrm{n}$ & $\%$ \\
\hline 1. & $\begin{array}{l}\text { Tobangen, } \\
\text { Mintjelungan }^{6}\end{array}$ & $\begin{array}{l}\text { Manado, } \\
\text { Indonesia }\end{array}$ & 3 & 4,2 & 2 & 2,8 & 25 & 35,2 & 17 & 24,0 & 17 & 24,0 & 7 & 9,8 \\
\hline 2. & Melda $^{13}$ & $\begin{array}{l}\text { Sidrap, } \\
\text { Indonesia }\end{array}$ & 21 & 19,1 & 0 & 0 & 47 & 42,7 & 16 & 14,6 & 26 & 23,6 & 0 & 0 \\
\hline 3. & Faruchy et al $^{14}$ & $\begin{array}{l}\text { Bandung, } \\
\text { Indonesia }\end{array}$ & 39 & 79,6 & 3 & 6,1 & 5 & 10,2 & 2 & 4,1 & - & - & - & - \\
\hline 4. & Multani $^{15}$ & India & 60 & 55,1 & 49 & 44,9 & - & - & - & - & - & - & - & - \\
\hline 5. & Nadeem et al ${ }^{16}$ & Pakistan & 24 & 23,3 & 8 & 7,8 & 16 & 15,5 & 55 & 53,4 & - & - & - & - \\
\hline 6. & $\operatorname{Tia}^{17}$ & $\begin{array}{l}\text { Aceh, } \\
\text { Indonesia }\end{array}$ & 1 & 0,7 & 0 & 0 & 117 & 78,5 & 11 & 7,4 & 20 & 13,4 & 0 & 0 \\
\hline 7. & 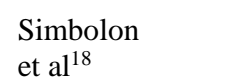 & $\begin{array}{l}\text { Medan, } \\
\text { Indonesia }\end{array}$ & 2 & 3,6 & 0 & 0 & 22 & 39,3 & 0 & 0 & 22 & 39,3 & 10 & 17,8 \\
\hline 8. & Sitepu ${ }^{19}$ & $\begin{array}{l}\text { Sumatera } \\
\text { Utara, } \\
\text { Indonesia }\end{array}$ & 15 & 18,3 & 7 & 8,5 & 19 & 23,2 & 18 & 21,9 & 19 & 23,2 & 4 & 4,9 \\
\hline 9. & $\begin{array}{l}\text { Nurisriani, } \\
\text { Firmansyah }^{20}\end{array}$ & $\begin{array}{l}\text { Polewali } \\
\text { Mandar, } \\
\text { Indonesia }\end{array}$ & 11 & 17,2 & 9 & 14,1 & 21 & 32,8 & 11 & 17,2 & 5 & 7,8 & 7 & 10,9 \\
\hline 10. & Yosadi et $\mathrm{al}^{21}$ & $\begin{array}{l}\text { Bolaang } \\
\text { Mongondo } \\
\text { w Timur, } \\
\text { Indonesia }\end{array}$ & 7 & 15,6 & 3 & 6,6 & 15 & 33,3 & 7 & 15,6 & 8 & 17,8 & 5 & 11,1 \\
\hline 11. & Triza, Afriza ${ }^{22}$ & $\begin{array}{l}\text { Padang, } \\
\text { Indonesia }\end{array}$ & 5 & 12,5 & 6 & 15,0 & 13 & 32,5 & 5 & 12,5 & 9 & 22,5 & 2 & 5,0 \\
\hline 12. & Pratiwi et $\mathrm{al}^{23}$ & $\begin{array}{l}\text { Padang, } \\
\text { Indonesia }\end{array}$ & 30 & 100 & 0 & 0 & 0 & 0 & 0 & 0 & - & - & - & - \\
\hline 13. & Rangkuti $^{24}$ & $\begin{array}{l}\text { Medan, } \\
\text { Indonesia }\end{array}$ & 49 & 37,1 & 0 & 0 & 53 & 40,2 & 1 & 0,7 & 29 & 22,0 & 0 & 0 \\
\hline 14. & Akbar et $\mathrm{al}^{25}$ & $\begin{array}{l}\text { Bandung, } \\
\text { Indonesia }\end{array}$ & 18 & 20,0 & 12 & 13,4 & 40 & 44,4 & 4 & 4,4 & 13 & 14,4 & 3 & 3,4 \\
\hline 15. & Hanioka et $\mathrm{al}^{26}$ & Jepang & 153 & 100 & 0 & 0 & - & - & - & - & - & - & - & - \\
\hline 16. & Haresaku et al ${ }^{27}$ & Jepang & 74 & 26,4 & 46 & 16,4 & 100 & 35,8 & 60 & 21,4 & - & - & - & - \\
\hline 17. & Goyal, Devaraj ${ }^{28}$ & India & 50 & 66,7 & 25 & 33,3 & - & - & - & - & - & - & - & - \\
\hline
\end{tabular}




\begin{tabular}{|c|c|c|c|c|c|c|c|c|c|c|c|c|c|}
\hline 18. Unsal et $\mathrm{al}^{29}$ & Turki & 101 & 37,7 & 29 & 10,8 & 95 & 35,4 & 43 & 16,1 & - & - & - & - \\
\hline 19. Fatimah et $\mathrm{al}^{30}$ & $\begin{array}{l}\text { Bandung, } \\
\text { Indonesia }\end{array}$ & 5 & 10,0 & 7 & 14,0 & 20 & 40,0 & 0 & 0 & 12 & 24,0 & 6 & 12,0 \\
\hline 20. Abdulnasser,Nasser & Brazil & 19 & 16,1 & 18 & 15,3 & 60 & 50,8 & 21 & 17,8 & - & - & - & - \\
\hline 21. Nwhator et $\mathrm{al}^{32}$ & Nigeria & 45 & 75,0 & 15 & 25,0 & - & - & - & - & - & - & - & - \\
\hline 22. Marakoglu et $\mathrm{al}^{33}$ & Turki & 180 & 29,6 & 30 & 4,9 & 398 & 65,5 & 0 & 0 & - & - & - & - \\
\hline
\end{tabular}

\section{BAHASAN}

Hasil penelitian pada 22 pustaka yang telah ditelaah (review), menunjukkan bahwa smoker's melanosis lebih banyak ditemukan pada responden yang merokok (22 pustaka) dibandingkan dengan responden yang tidak merokok (21 pustaka), sedangkan yang tidak mengalami smoker's melanosis ditemukan dalam jumlah yang sama pada keduanya yaitu pada responden yang merokok dan tidak merokok (21 pustaka). Hal ini sejalan pernyataan Nikitakis dan Brooks ${ }^{5}$ bahwa 98\% rongga mulut perokok menampilkan lebih banyak lesi abnormal, salah satunya smoker's melanosis, dibandingkan rongga mulut non perokok. Hal ini didukung pula oleh penelitian Motamayel et $\mathrm{al}^{34}$ di Iran yang menyebutkan bahwa smoker's melanosis terjadi lebih banyak pada perokok yakni $75 \%$ sedangkan pada non perokok hanya $25 \%$.

Fauzani ${ }^{35}$ menyatakan bahwa timbulnya lesi smoker's melanosis sangat erat kaitannya dengan aktivitas merokok yang dilakukan oleh seseorang, dimana aktivitas seorang perokok dapat dilihat dari frekuensi merokok, durasi merokok dan jenis rokok yang dikonsumsi. Frekuensi merokok adalah jumlah rokok yang dihisap dalam satuan batang per hari. ${ }^{36}$ Semakin sering frekuensi merokok dilakukan maka akan semakin tinggi kandungan nikotin dalam tubuh. ${ }^{37}$ Terdapat tiga tipe perilaku merokok menurut banyaknya rokok yang dihisap yaitu perokok berat yang menghisap $>15$ batang rokok per hari; perokok sedang yang menghisap 5-14 batang rokok per hari; dan perokok ringan yang menghisap $\pm 1-4$ batang rokok per hari. ${ }^{38}$ Berdasarkan frekuensi merokok, hasil yang diperoleh dalam penelitian ini menunjukkan bahwa smoker's melanosis paling banyak ditemukan pada perokok berat (22 pustaka), diikuti perokok sedang (21 pustaka), dan perokok ringan (15 pustaka). sedangkan yang tidak mengalami smoker's melanosis paling banyak ditemukan pada perokok ringan (21 pustaka), diikuti dengan perokok sedang (19 pustaka) dan perokok berat (10 pustaka). Hal ini sejalan dengan pernyataan Hedin et $\mathrm{al}^{39}$ yaitu jumlah pigmentasi melanin gingiva berpengaruh secara bermakna dengan jumlah rokok yang dikonsumsi dalam satu hari. Semakin banyak jumlah rokok yang dikonsumsi dalam satu hari maka semakin tinggi risiko pigmentasi melanin gingiva terjadi, demikian pula sebaliknya semakin sedikit jumlah rokok yang dikonsumsi dalam satu hari maka semakin rendah risiko pigmentasi melanin gingiva terjadi. Penelitian yang dilakukan oleh Behura et $\mathrm{al}^{40} \mathrm{di}$ India juga melaporkan bahwa berdasarkan kategori perokok, persentase terbesar yang tidak menampilkan smoker's melanosis yaitu perokok ringan (50\%), lalu perokok sedang (35\%) dan perokok berat (15\%).

Durasi merokok adalah rentang waktu atau lamanya kegiatan merokok berlangsung dalam skala tahunan. ${ }^{36}$ Durasi atau lama merokok suatu individu bisa didapatkan dari current smoker's yang terbagi menjadi tiga, yaitu: $1=<5$ tahun, $2=5-9$ tahun, $3=10-14$ tahun. ${ }^{41}$ Berdasarkan durasi merokok, hasil penelitian ini menunjukkan bahwa yang mengalami smoker's melanosis paling banyak ditemukan pada perokok yang merokok >10 tahun (22 pustaka), diikuti dengan perokok yang merokok 5-10 tahun (21 pustaka) dan perokok merokok $<5$ tahun (18 pustaka) sedangkan yang tidak mengalami smoker's melanosis paling banyak ditemukan pada perokok yang merokok <5 tahun dan 5-10 tahun (18 pustaka), diikuti perokok yang merokok $>10$ tahun (17 pustaka). Nadeem et $\mathrm{al}^{16}$ di Pakistan menyebutkan bahwa smoker's 
melanosis berkaitan dengan durasi merokok. Hal ini sejalan dengan pernyataan Valerie et $\mathrm{al}^{42}$ yang menyebutkan bahwa semakin lama merokok, semakin tinggi kandungan melanin dalam jaringan ikat gusi dan semakin besar kemungkinan terjadinya melanosis rongga mulut. Hasil penelitian ini didukung pula oleh penelitian yang dilakukan oleh Mirbod dan Ahing ${ }^{43}$ di Kanada yang menyebutkan bahwa $45 \%$ subjek yang merokok lebih dari 10 tahun menunjukkan angka tertinggi mengalami smoker's melanosis, 35\% yang merokok 5-10 tahun berada di urutan menengah, dan sisanya ditemukan pada perokok yang merokok tidak lebih dari 5 tahun. $^{44}$

Jenis rokok dibagi berdasarkan penggunaan filter yaitu rokok filter dan nonfilter. Rokok filter merupakan rokok yang bagian pangkalnya terdapat gabus, sedangkan rokok nonfilter merupakan rokok yang pada bagian pangkalnya tidak terdapat gabus. ${ }^{35}$ Berdasarkan bahan bakunya, rokok dapat dibedakan menjadi rokok putih dan kretek. Rokok putih adalah rokok tanpa campuran cengkeh, sedangkan rokok kretek adalah rokok yang terbuat dari campuran tembakau dan cengkeh dengan lima bahan kimia yang terbanyak yaitu eugenol, acetyl eugenol, B-caryophyllene, x-humulene serta caryophllrn epoksida. ${ }^{9}$ Berdasarkan bahan pembungkusnya, rokok dikenal dengan istilah sigaret. Rokok sigaret dibagi lagi menjadi dua jenis berdasarkan proses pembuatannya, yakni rokok sigaret kretek tangan (SKT) dan sigaret kretek mesin $(\mathrm{SKM}){ }^{36}$ Berdasarkan jenis rokok, hasil yang diperoleh dalam penelitian ini menunjukkan bahwa yang mengalami smoker's melanosis paling banyak ditemukan pada perokok dengan jenis rokok kretek/non filter/sigaret kretek (22 pustaka), diikuti perokok dengan jenis rokok putih/filter (17 pustaka) dan perokok dengan jenis keduanya yaitu kretek dan putih/non filter dan filter (11 pustaka), sedangkan yang tidak mengalami smoker's melanosis paling banyak ditemukan pada perokok dengan jenis rokok kretek/non filter/sigaret kretek (16 pustaka), diikuti perokok dengan jenis rokok putih/filter (14 pustaka), dan perokok dengan jenis keduanya yaitu kretek dan putih/non filter dan filter (8 pustaka). Jenis rokok yang dikonsumsi turut menjadi faktor risiko yang dapat menimbulkan smoker's melanosis. ${ }^{45} \mathrm{Hal}$ ini sejalan dengan pernyataan Laskaris ${ }^{44}$ yang menyebutkan bahwa 25-31\% perokok dengan jenis rokok non filter menampakkan derajat smoker's melanosis yang lebih tinggi. Hal ini juga didukung oleh Sukendro ${ }^{36}$ yang menyatakan bahwa jenis rokok sigaret memiliki komposisi yang sama dengan rokok kretek yaitu terbuat dari campuran tembakau dan cengkeh. Penelitian yang dilakukan oleh Mattoo et $\mathrm{al}^{46}$ di India melaporkan hal yang berbeda yaitu dari 71 perokok, yang paling banyak tidak menampakkan smoker's melanosis yaitu perokok dengan jenis rokok putih. Adanya perbedaan hasil penelitian ini dengan penelitian lainnya dapat disebabkan oleh jumlah sampel pada perokok dengan jenis rokok putih lebih banyak mengalami smoker's melanosis dibandingkan yang tidak mengalami smoker's melanosis.

\section{SIMPULAN}

Smoker's melanosis lebih banyak didapatkan pada perokok dibandingkan dengan yang bukan perokok, terutama pada perokok berat, durasi merokok $>10$ tahun, dan jenis rokok kretek/non filter/sigaret kretek.

\section{Konflik Kepentingan}

Penulis menyatakan tidak terdapat konflik kepentingan dalam studi ini.

\section{DAFTAR PUSTAKA}

1. Kusuma ARP. Pengaruh merokok terhadap kesehatan gigi dan rongga mulut. Majalah Ilmiah Universitas Sultan Agung. 2011;59(2):1-8. 2020

2. WHO. Tobacco: Deadly in any form or disguise. Geneva: WHO, 2015; p. 12.

3. Badan Penelitian dan Pengembangan Kesehatan. Hasil utama Riskesdas 2018. Jakarta: Kemenkes RI, 2018; p. 90.

4. Djokja RM, Lampus BS, Mintjelungan C. Gambaran perokok dan angka kejadian lesi mukosa mulut di desa Monsongan Kecamatan Banggai Tengah. e-GiGi. 2013;1(1):38-44. 
5. Nikitakis NG, Brooks JK. Diffuse oral mucosal pigmentations. General Dentistry, 2010; 58(2):151-4.

6. Tobangen PA, Mintjelungan C. Gambaran kebiasaan merokok pada mahasiswa Fakultas Kedokteran Universitas Sam Ratulangi dengan lesi yang diduga smoker's melanosis. e-Gigi. 2011;1(1): 26.

7. Yerger VB, Malone RE. Melanin and nicotine: a review of the literature. Nicotine \& Tobacco Research. 2006;8(4):487-98.

8. Sharath KS, Rahul S, Thomas B, Madani SM, Shetty S. Gingival depigmentation: case series for four different techniques. Nitte University Journal of Health Sciences (NUJHS). 2013;3(4):132-6.

9. Roshna T, Nandakumar K. Anterior esthetic gingival depigmentation and crown lengthening: report of a case. J Contemp Dent Pract. 2005;6(3):139-47.

10. Coleman GC, Nelson JF. Principles of Oral Diagnosis. Nevada: St Louis Mosby, 1999; p. 325.

11. Grennberg MS, Glick M, Ship J. Burket's Oral Medicine (11th ed). Hamilton: BC Decker Inc, 2008; p. 132.

12. Berkmoes RV, Brash C, Cohen M, Elliot M, Mitra G, Noble J, et al. Indonesia (9th ed). Melbourne: Lonely Planet, 2010; p. 216.

13. Melda. Prevalensi smoker's melanosis pada kalangan petani. Studi pada petani perokok Kecamatan Panca Rijang Kabupaten Sidrap. Dentomaxillofacial. 2014; 1(1):28.

14. Faruchy AG, Komara I, Pribadi IMS. Prevalensi hiperpigmentasi gingiva pada pasien perokok di klinik periodonsia Rumah Sakit Gigi dan Mulut. Padjajaran J Dent Res Student. 2018;2(1):1-5.

15. Multani SMDS. Interrelationship of smoking, lip and gingival melanin pigmentation, and periodontal status. Addict Health, 2013;5(1-2):57-65.

16. Nadeem M, Yaldrum A, Shafique R, Lopez R. Intraoral distribution of oral melanosis and cigarrette smoking in a Pakistan population. International Journal of Dental Clinics. 2011;3(1):c25-28.

17. Tia CDS. Hubungan antara frekuensi, durasi, jenis rokok, dan kadar nikotin dengan smoker's melanosis pada mahasiswa Fakultas Teknik Universitas Syiah Kuala [Electronic Thesis and Dissertations/
ETD). Aceh: Universitas Syiah Kuala; 2015.

18. Simbolon GJ, Sartini, Fauziah I. Hubungan kebiasaan merokok terhadap smoker's melanosis pada siswa SMA HKBP Sidorame Medan. BioLink, Jurnal Biologi Lingkungan, Industri, Kesehatan. 2016;3(1):37-43.

19. Sitepu LS. Hubungan kebiasaan merokok terhadap terjadinya smoker's melanosis di kalangan mahasiswa Fakultas Matematika dan Ilmu Pengetahuan Alam Universitas Sumatera Utara. Repository Universitas Sumatera Utara. 2010;2(1): 7-16.

20. Nurisriani, Firmansyah A. Hubungan kebiasaan merokok dengan timbulnya tandatanda smoker's melanosis di Lingkungan Pokko Kecamatan Anreapi Kabupaten Polewali Mandar. Jurnal Kesehatan Bina Generasi. 2017; 9(1):7-13.

21. Yosadi ZD, Rompas S, Bawotong J. Hubungan kebiasaan merokok dengan terjadinya smoker's melanosis pada kalangan petani di Desa Tutuyan 1 Kecamatan Tutuyan Kabupaten Bolaang Mongondow Timur. e-Journal Keperawatan (eKp). 2015;3(3):4-9.

22. Triza Y, Afriza D. Hubungan kebiasaan merokok dengan melanosis perokok di Rumah Sakit Gigi dan Mulut Baiturrahmah. Jurnal B-Dent. 2014;1(2):90-6.

23. Pratiwi WO, Lestari C, Bakar A. Prevalensi dan distribusi smoker's melanosis pada buruh bangunan yang perokok di PT. Trikencana Sakti Utama Ketaping. Jurnal B-Dent. 2017;4(1):23-31.

24. Rangkuti PA. Pengaruh kebiasaan merokok terhadap status periodontal dan pigmentasi melanin gingiva pada pegawai di kantor PT. Perkebunan Nusantara 3 Medan. Repository Universitas Sumatera Utara. 2019;3(1):38-43.

25. Akbar RR, Widyaputra S, Kintawati S. Relationship between filter cigarettes smoking habits with the appearance of smoker's melanosis: observation of smoking duration and the amount of cigarettes consumption. Padjadjaran Journal of Dentistry. 2007;18(1):1-5.

26. Hanioka T, Tanaka M, Tamagawa H, Shizukuishi S. Epidemiologic study of melanin pigmentation in the attached gingiva in relation to cigarette smoking. Journal of Dental Health. 1993;43(1):40-7. 
27. Haresaku S, Hanioka T, Tsutsui A, Watanabe T. Association of lip pigmentation with smoking and gingival melanin pigmentation. Oral Diseases. 2007;13(1):71-6.

28. Goyal V, Devaraj CG. Correlation of smoking, periodontal health status and gingival melanin pigmentation. International Journal of Health Sciences and Research. 2017;7(1):109-14.

29. Unsal E, Paksoy C, Soykan E, Elhan AH, Sahin M. Oral pigmentation related to smoking in a Turkish population. Community Dental Oral Epidemiol. 2001;29(4):2727.

30. Fatimah A, Tjahajawati S, Rizali E. Pigmentation lesions and salivary flow rates on woman smokers. Dentika Dental Journal. 2019;22(2):34-8.

31. Abdulnasser WAL, Nasser MAL. Prevalence of melanin pigmentation in a Yemeni population and its relation to some risk factors. Brazilian Dental Sciences. 2019;23(2):1-9.

32. Nwhator SO, Winfunke-Savage K, Ayanbadejo P, Jeboda SO. Smoker's melanosis in a Nigerian population: a preliminary study. J Contemp Dent Pract. 2017;8(5):1-9.

33. Marakoğlu K, Gürsoy UK, Toker HC, Demirer S, Sezer RE, Marakoğlu I. Smoking status and smoke related gingival melanin pigmentation in army recruitments. Military Medicine. 2010; 172(1):110.

34. Motamayel FA, Falsafi P, Hayati Z, Rezaei F, Poorolajal J. Prevalence of oral mucosal lesions in male smoker's and nonsmoker's. Chonnam Medical Journal. 2013;49(2):65.

35. Fawzani N. Terapi berhenti merokok: studi kasus 3 perokok berat. Makara Kese- hatan. 2015;9(1):15-22.

36. Sukendro S. Filosofi Rokok. Yogyakarta: Pinus Book Publisher, 2017; p. 31-41, 80-4.

37. Jaya M. Pembunuh Berbahaya Itu Bernama Rokok. Yogyakarta: Riz'ma, 2009; p. 49-50.

38. Smet B. Psikologis Kesehatan akibat Rokok. Semarang: PT Gramedia, 2015; p. 17.

39. Hedin CA, Pindborg JJ, Axell T. Disappearance of smoker's melanosis after reducing smoking. J Oral Pathol Med. 1993;22(5):228-30.

40. Behura SS, Masthan MK, Narayanasamy AB. Oral mucosal lesions associated with smokers and chewers: a case control study in Chennai population. Journal of Clinical and Diagnostic Research (JCDR). 2015;9(7):17-22.

41. Novak MJ, Novak KF, Preshaw PM. Smoking and periodontal disease. In: Newman M, Takei H, Klokkevold P, Carranza F, editors. Carranza's Clinical Periodontology (11th ed). Philadelphia: Elsevier Saunders, 2012; p. 294-5.

42. Valerie BY, Malone RE. Melanin and nicotine: a review of the literature. Nicotine Tob Res. 2006;8(4):487-98.

43. Mirbod SM, Ahing SI. Tobacco associated lesions of the oral cavity: part I. nonmalignant lesions. J Can Dent Assoc. 2000;66(5):252-6.

44. Laskaris G. Color Atlas of Oral Disease. Stuttgart: Georg Thieme Verlag, 2006; p. 45.

45. Kumar H, Chaturvedi P. Oral melanosis. International Journal of Head and Neck Surgery. 2011;2(2):121-23.

46. Mattoo K, Singh M, Arora P. Bilateral smoker's melanosis. Med Res Chron. 2014:1(2):97-101. 